\title{
PERANCANGAN APLIKASI ABSENSI PESERTA BIMBINGAN BELAJAR BERBASIS WEB DENGAN MENGGUNAKAN FRAMEWORK YII
}

\author{
Sri Rahayu ${ }^{1}$ \\ Muhamad Yusup ${ }^{2}$ \\ Sinta Puspita Dewi ${ }^{3}$ \\ Alumni Magister Manajemen Sistem Informasi Univ Gunadarma ${ }^{1}$, Alumni Magister Ilmu Komputer \\ Univ Budi Luhur Jakarta ${ }^{2}$, Mahasiswa STMIK Raharja ${ }^{3}$ \\ email:srirahayu@raharja,yusup@raharja.info,shinta@raharja.info
}

Diterima : 10 Februari 2015/ Disetujui : 18 Maret 2015

\begin{abstract}
Activities attendance of participants in a learning institution is generally done every meeting in order to determine whether students are sick, license, negligent, or late for any class. Then, the data will be entered into the data absentee participant, the participant data include NIP, Name, Class.. Attendance data on the participants learning institution can be used as an assessment to the level of discipline on each participant. It also serves to obtain attendance data summary for each participant at the end of the meeting. Attendance data of pre-existing participants can not meet the needs of the user at the time of charging participants for attendance officers are still using manual attendance register. Attendance manually participants will encounter some problems such as easily wear away, difficulty in data retrieval and slow time in the data processing is considered a need for change in a computerized system so that the information obtained are more accurate. It is because the system uses a database, where the data is stored in an integrated way. Construction of the system by using web yii framework has advantages which are small data size, the Security Concern framework to anticipate and put up a shield against the various security issues that may arise.
\end{abstract}

Keyword: Attendence, Framework, Yii

ABSTRAK

Kegiatan absensi peserta di sebuah lembaga pembelajaran pada umumnya dilakukan setiap pertemuan dengan tujuan untuk mengetahui apakah siswa sakit, ijin, alpa, atau terlambat. untuk setiap kelas. Kemudian data ini akan masuk ke data absensi peserta, data peserta tersebut diantaranya adalah NIP, Nama, Kelas. Data absensi peserta pada lembaga pembelajaran ini dapat dijadikan penilaian untuk tingkat kedisiplinan pada setiap peserta. Hal ini juga berfungsi untuk mendapatkan rekapitulasi data absensi untuk setiap peserta pada akhir pertemuan. Data absensi peserta yang sudah ada sebelumnya tidak bisa memenuhi kebutuhan pengguna pada saat melakukan pengisian absensi peserta karena petugas masih menggunakan daftar hadir secara manual. Absensi peserta secara manual akan menemui beberapa kendala diantaranya mudah tercecer, sulitnya dalam pencarian data serta lambatnya waktu dalam pengolahan data maka di anggap perlunya perubahan sistem secara komputerisasi sehingga informasi yang didapat lebih akurat. Hal ini karena sistem ini menggunakan database, di mana data disimpan secara terintegrasi. Pembangunan sistem dengan mengunakan web framework yii memiliki kelebihan diantaranya adalah memiliki ukuran data yang kecil, Security Concern framework mengantisipasi dan memasang perisai terhadap adanya berbagai masalah keamanan yang mungkin timbul. 
Kata kunci : Absensi, Framework, Yii

\section{PENDAHULUAN}

Seiring tumbuh kembangnya lembaga pembelajaran dan berkembangnya ilmu pengetahuan di segala bidang dalam era globalisasi saat ini yang begitu pesat. Perkembangan ini membuat banyak pekerjaan manusia yang digantikan oleh komputer. Sehingga dalam suatu lembaga pembelajaran banyak yang harus dilakukan perubahan yang memacu pada era globalisasi ini.

Absensi peserta belajar dalam lembaga pembelajaran adalah salah satu perubahan yang harus dilakukan karena memiliki peranan penting bagi perusahaan.dimana absensi merupakan salah satu penunjang yang dapat mendukung atau memotivasi setiap kegiatan didalamnya. Disamping itu absensi peserta ini dapat juga menjadi informasi tentang bagaimana kedisiplinan peserta yang bersangkutan . penting adanya bagi pembimbing/pementor dalam lembaga pembelajaran untuk mengetahui kehadiran pesertanyanya, baik yang sering datang tepat waktu maupun yang datang terlambat.

Pada umumnya banyak lembaga pembelajaran yang masih menggunakan absensi manual apalagi lembaga pembelajaran yang baru memulai usaha. Sistem dengan cara manual yaitu dengan cara mengisi nama dan tanda tangan pada buku absensi yang sudah di sediakan lembaga pembalajaran.

Dalam sistem absensi secara manual menimbulkan beberapa masalah yaitu, peserta dapat memanipulasi jam kedatangan ataupun jam pulang dan bisa juga menuliskan nama teman yang jelas jelas tidak hadir. Selain itu proses yang dilakukan cukup memakan banyak waktu dan tenaga sehingga sistem ini tidak efektif dan kurang akurat. Karena adanya berbagai permasalahan tersebut. Penulis bermaksud untuk membuat sistem pencatatan absensi yang berbasis web yang tentunya efektif, akurat dan ramah biaya.

Berawal dari uraian permasalahan diatas maka menarik untuk dibuatnya suatu sistem informasi absensi peserta di suatu lembaga pembelajaran yang diimplementasikan dalam 1 bentuk perangkat lunak yang sudah terkomputerisasi, maka pada jurnal ini mengambil topik "PERANCANGAN APLIKASI PENDATAAN ABSENSI PESERTA BERBASIS WEB DENGAN MENGGUNAKAN FRAMEWORK YII ".

\section{PERMASALAHAN}

Berdasarkan pada latar belakang masalah yang diuraikan diatas, terdapat permasalahan yang terjadi yaitu proses absensi peserta dilakukan secara manual untuk peserta yang berhalangan hadir, dalam hal ini keterangan yang dimasukan dalam buku absensi adalah sakit, izin, alpa, atau terlambat. Proses absensi peserta yang dilakukan masih belum memiliki database yang mengelola data absensi peserta. Rekapitulasi data absensi peserta dan data kelas dilakukan secara manual per pertemuan tanpa dilakukan printout laporan.

\section{LANDASAN TEORI}

\section{Pengertian Yii Framework}

Yii merupakan salah satu dari sederetan PHP Framework yang bersifat open source. Berdasarkan situs resminya, Yii adalah Framework (kerangka kerja) PHP berbasis komponen, berkinerja tinggi untuk pengembangan aplikasi web berskala besar. Yii juga meyediakan reusability maksimum dalam 
pemrograman web dan mampu meningkatkan kecepatan pengembangan secara signifikan. Nama YII singkatan dari Yes It Is. [8].

\section{Manfaat Yii Framework}

\section{Adapun manfaat dari Yii}

Framework adalah sebagai berikut:

1. Manfaatnya dapat membantu kerja developer dalam membangun aplikasi sehingga aplikasi bisa selesai dalam waktu yang singkat.

2. Penerapan Design Patterns memudahkan dalam rancangan, pengembangan dan pemeliharaan sistem.

3. Stability dan Reliability aplikasi yang kita bangun lebih stabil dan handal karena berbasis pada framework yang sudah teruji stabilitas dan kehandalannya.

4. Coding Style konsisten, memudahkan dalam membaca kode dan dalam menemukan bugs.

5. Security Concern framework mengantisipasi dan memasang perisai terhadap adanya berbagai masalah keamanan yang mungkin timbul.

6. Dokumentasi, framework dapat mendisiplinkan kita untuk menulis dokumentasi untuk apa yang kita tulis.

\section{Cara Kerja Yii}

Secara singkat dapat kita katakan bahwa Model merupakan kerangka dari proses-proses bisnis yang akan mendukung fungsi dan fasilitas pada website kita. Model ini didefinisikan dengan class-class tertentu dengan fungsifungsi yang spefisik untuk setiap class. Class ini nantinya akan dipanggil sebagai objek pada controller atau langsung pada view sesuai fungsi dan kebutuhannya. Semua fungsi yang berkaitan dengan database seperti create, read, update, delete akan diletakkan pada Model. Pemrosesannya lebih lanjut dari database tersebut ataupun dari variabel dan atribut lain bila tidak dari database akan diolah lebih lanjut di Model ini hingga nantinya menghasilkan output yang sesuai kebutuhan dan dapat dibaca dengan baik dari view maupun controller. View terdiri dari barisan kode program yang mengatur tampilan. Karena itu sebagian besar dari kode view ini akan berisikan kode HTML. Kalaupun menggunakan pengolahan dengan PHP atau javascript itu hanya untuk membantu menampilkan data dari variabel atau array atau dari model yang sudah siap untuk ditampilkan. Controller disini berfungsi sebagai perantara antara View dan Model. Kode program Controller biasanya juga terdiri dari classclass tertentu, namun memiliki fungsi yang berbeda dari Model. Fungsi dari Class disini biasanya hanya sebagai perantara untuk mengelompokkkan fungsifungsi tertentu dari Model dan mengembalikan nilainya ke view dengan cara di-render.

\section{Pengenalan PHP}

PHP adalah kependekan dari Personal Home Page. Rasmus Ledofrf adalah pencipta bahasa pemrograman PHP pada tahun 1995 yang pada masa itu masih di kenal dengan nama Form Interpreted (FI). Pada November 1997, dirilis PHP/FI 2.0. Pada rilis ini, interpreter PHP sudah diimplementasikan dalam program $\mathrm{C}$. Dalam rilis ini disertakan juga modulmodul ekstensi yang meningkatkan kemampuan PHP/FI secara signifikan [3].

PHP adalah bahasa server - side scripting yang menyatu dengan HTML untuk membuat halaman web yang dinamis. Maksud dari server - side scripting adalah sintaks dan perintah perintah yang diberikan akan sepenuhnya dijalankan di server. Tetapi disertakan pada dokumen HTML. Pembuatan web ini merupakan kombinasi antara PHP sendiri sebagai bahasa pemprograman dan HTML sebagai pembangun halaman web. Ketika 
seorang pengguna internet akan membuka suatu situs yang menggunakan fasilitas server - side scripting PHP, maka terlebih dahulu server yang bersangkutan akan memproses semua perintah PHP di server lalu mengirimkan hasilnya dalam format HTML ke web browser pengguna internet tadi. Dengan demikian seorang pengguna internet tidak dapat melihat kode program yang ditulis dalam PHP sehingga keamanan dari halaman web menjadi lebih terjamin. $[\mathrm{X}]$

\section{Database}

Database (basis data) adalah kumpulan data yang terintegrasi dan diatur sedemikian rupa sehingga data tersebut dapat dimanipulasi, diambil, dan dicari secara cepat [7]. Perangkat lunak yang digunakan untuk mengelola dan memanggil kueri (query) basis data disebut sistem manajemen basis data (database management system, DBMS). Sistem basis data dipelajari dalam ilmu informasi. Istilah "basis data" berawal dari ilmu komputer. Meskipun kemudian artinya semakin luas, memasukkan hal-hal di luar bidang elektronika, artikel ini mengenai basis data komputer. Catatan yang mirip dengan basis data sebenarnya sudah ada sebelum revolusi industri yaitu dalam bentuk buku besar, kuitansi dan kumpulan data yang berhubungan dengan bisnis. Konsep dasar dari basis data adalah kumpulan dari catatan-catatan, atau potongan dari pengetahuan. Sebuah basis data memiliki penjelasan terstruktur dari jenis fakta yang tersimpan di dalamnya: penjelasan ini disebut skema. Skema menggambarkan obyek yang diwakili suatu basis data, dan hubungan di antara obyek tersebut. Ada banyak cara untuk mengorganisasi skema, atau memodelkan struktur basis data: ini dikenal sebagai model basis data atau model data. Model yang umum digunakan sekarang adalah model relasional, yang menurut istilah layman mewakili semua informasi dalam bentuk tabel-tabel yang saling berhubungan dimana setiap tabel terdiri dari baris dan kolom (definisi yang sebenarnya menggunakan terminologi matematika). Dalam model ini, hubungan antar tabel diwakili denga menggunakan nilai yang sama antar tabel. Model yang lain seperti model hierarkis dan model jaringan menggunakan cara yang lebih eksplisit untuk mewakili hubungan antar tabel. Istilah basis data mengacu pada koleksi dari data-data yang saling berhubungan, dan perangkat lunaknya seharusnya mengacu sebagai sistem manajemen basis data (database management system/DBMS). Jika konteksnya sudah jelas, banyak administrator dan programer menggunakan istilah basis data untuk kedua arti tersebut.

\section{LITERATURE REVIEW}

Banyak penelitian yang sebelumnya dilakukan mengenai sistem absensi. Dalam upaya pengembangan sistem absensi ini perlu dilakukan studi pustaka sebagai salah satu dari penerapan metode penelitian yang akan dilakukan. Diantaranya adalah mengidentifikasikan kesenjangan (identify gaps), menghindari pembuatan ulang (reinventing the wheel), mengidentifikasikan metode yang pernah dilakukan, meneruskan penelitian sebelumnya, serta mengetahui orang lain yang spesialisasi dan area penelitiannya sama dibidang ini. Beberapa Literature review tersebut adalah sebagai berikut :

1. Penelitian yang dilakukan oleh Rachman Mulyandi dan Cynthia Ayu Wulan Dini pada tahun 2014 yang berjudul "Aplikasi Absensi Pegawai Kecamatan Batuceper Tangerang Dalam Meningkatkan Akurasi Informasi". Penelitian ini menjelaskan perihal Kecamatan Batuceper yang merupakan instansi pemerintahan yang sistem absensi pegawainya masih 
berjalan secara manual. Dimana dalam penerapan sistem absensi ini terdapat beberapa hal yang menjadi kendala. Adapun kendala yang terjadi yaitu dalam hal keefektifan, efisiensi waktu dan proses pengabsenan. Bentuk laporan absensi yang ada saat ini masih berupa tulisan yang dapat menyulitkan dalam proses pencarian data, dan kemungkinan terjadinya data absensi yang hilang. Dengan alasan di atas maka penulis mencoba untuk memberikan alternatif pemecahan masalah dengan membuat suatu aplikasi sistem absensi yang akan mencatat daftar kehadiran pegawai, waktu kedatangan, waktu pulang, yang akan dibuat secara sistematis dan terkomputerisasi. Sistem ini menghilangkan proses pencatatan kehadiran pegawai yang selama ini masih berjalan secara manual, yaitu dengan mengurangi tingkat kesalahan dengan cara menginputkan nomor induk pegawai dalam proses absensi tersebut. Pada penulisan ini juga akan diterangkan tahapan pengerjaan, mulai dari proses analisa, perencanaan, perancangan dengan menggunakan bahasa pemograman PHP (Hypertext Prepocessor) dan database MySQL, hingga tahapan pengimplementasian dengan menggunakan metode spiral dengan notasi perekayasaan dan pendekatan berorientasi objek, UML (Unified Modelling Languange), dengan tujuan untuk mengetahui data apa saja yang menjadi masukan dan keluaran pada sistem yang berjalan. Dengan adanya sistem informasi absensi diharapkan dapat meminimalkan kendala-kendala yang terjadi pada sistem sebelumnya. [5].

2. Penelitian yang dilakukan oleh Alfien S.Rintjap, Sherwin R.U.A, Sompie, dan Oktavian Lantang pada tahun 2014 berjudul "Aplikasi Absensi Siswa Menggunakan Sidik Jari di Sekolah Menengah Atas Negeri 9 Manado". Penelitian ini mejelaskan perihal perkembangan ilmu pengetahuan di segala bidang dalam era globalisasi saat ini begitu pesat terutama dalam bidang IT yang semakin maju seiring dengan kebutuhan pemakai (user). absensi merupakan salah satu penunjang yang dapat mendukung atau memotivasi setiap kegiatan yang dilakukan di dalam dunia pendidikan di Indonesia pada saat ini, terutama dalam setiap proses kegiatan belajar. Penggunaan sidik jari untuk absensi siswa bisa menjadisolusi cara absensi yang lebih baik. yang diharapkan dapat mengatasi permasalahan dan meningkatkan kinerja di Sekolah. Tugas akhir dengan judul Aplikasi Absensi Siswa Menggunakan Sidik Jari di SMA N 9 Manado ini bertujuan untuk memperbaiki sistem absensi yang dilakukan dengan cara manual. Pengembangan aplikasi dilakukan dengan menggunakan bahasa pemprograman VB. Net dan menggunakan mesin fingerprintsebagai alat untuk merekan sidik jari. Dari hasil implementasi aplikasi ini dapat disimpulkan bahwa aplikasi ini memberikan manfaat menghindari terjadinya manipulasi data, menghemat waktu dalam melakukan absensi. [1].

3. Penelitian ini dilakukan oleh Aditya Tegar Satria pada tahun 2013 berjudul "Rancang Bangun Sistem Absensi Karyawan Online Berbasis Web Menggunakan Framework PHP Codeigniter \& Mysql (Studi Kasus: PT. Starone Mitra Telekomunikasi)". Penelitian ini membahas tentang PT StarOne Mitra Telekomunikasi masih menerapkan sistem absen petunjuk sebagai sistem karyawan kehadiran pada hari ini, dilaksanakan untuk setiap karyawan dalam lembar bentuk kehadiran disediakan sehari-hari. Seiring dengan berjalannya waktu dengan, sistem ini terbukti persyaratan kurang efisiensi dan akurasi data. Penelitian ini memberikan merancang 
karyawan sistem online absen berbasis web menggunakan framework PHP CodeIgniter untuk membangun antarmuka situs dan perangkat lunak MySQL sebagai sistem basis data, juga menggunakan metode waterfall pengembangan sistem. Karyawan secara online sistem absen berbasis web ini dimaksudkan untuk menutupi kekurangan sistem absen manual, meningkatkan efisiensi dan akurasi data absensi, memfasilitasi kehadiran karyawan, dan juga membantu manajemen untuk memantau semua karyawan hadir \& kinerja. [2].

4. Penelitian yang dilakukan oleh Noval Aditya Muhammad, Febriliyan Samopa dan Radityo Prasetianto Wibowo pada tahun 2013, dengan judul "Pembuatan Aplikasi Presensi Perkuliahan Berbasis Fingerprint (Studi Kasus : Jurusan Sistem Informasi Institut Teknologi Sepuluh Nopember Surabaya)". Penelitian ini membahas tentang Jurusan Sistem Informasi Institut Teknologi Sepuluh November Surabaya (JSI ITS) dewasa ini telah menerapkan sistem absensi berbasis fingerprint guna menunjang proses belajar mengajar, serta menanggulangi kecurangan presensi di kelas. Teknologi ini memang sedang marak dan sangat mendukung karena penerapannya tidak terlalu sulit lagipula terjangkau. Tetapi JSI belum memaksimalkan penerapan presensi fingerprint tersebut karena belum memiliki aplikasi yang mengelola presensi tersebut. JSI menggunakan perangkat keras VF30 fingerprint yang telah teraplikasi pada setiap ruang kelas. Sistem akan bekerja jika VF30 fingerprint diaktifkan oleh guratan sidik jari user, yang kemudian dikirim ke server untuk proses authentification dan recording. Sebuah web-based application akan menjadi wadah aplikasi VF30 dengan presensi akademik. Aplikasi ini diharapkan dapat membantu menaggulangi masalah kecurangan presensi yang sering terjadi serta memberikan kemudahan untuk melakukan rekapitulasi presensi mahasiswa selama proses belajar mengajar setiap harinya. [6].

5. Penelitian yang dilakukan Lidya Anjaya, Roni Lukito, dan Edin Surdi Djatikusuma pada tahun 2010 yang berjudul "Sistem Informasi Manajemen Kepegawaian Berbasis $W e b$ pada PT Bintang Baru Sejati Palembang". Penelitian ini menjelaskan Sistem Informasi Manajemen merupakan penerapan sistem informasi di dalam organisasi untuk mendukung informasi-informasi yang dibutuhkan oleh semua tingkatan manajemen. Tujuan skripsi ini adalah untuk me rancang sistem informasi manajemen kepegawaian pada PT Bintang Baru Sejati Palembang. Metode yang digunakan adalah metode FAST (Framework for the Application of System Thinking). Perancangan dan inplementasi akan dilakukan dengan bahasa pemrograman PHP (Personal Home Page) yang kini lebih dikenal dengan Hypertext Preprocessing dan basis data MySQL (Structure Query Language). Sistem ini diharapkan dapat membantu manajer puncak pada PT Bintang Baru Sejati Palembang dalam pengelolaan kepegawaian. [4].

Dari lima literature review yang ada, telah banyak penelitian mengenai sistem absensi dalam membuat laporan kehadiran, namun dapat disimpulkan pula bahwa belum ada peneliti yang secara khusus membahas mengenai perancangan Aplikasi Absensi Peserta Berbasis Web Dengan Menggunakan Framework Yii yang digunakan sebagai media informasi dan aplikasi pengelolaan data absensi harian peserta berbasis database.

\section{PEMECAHAN MASALAH}


Adapun maksud dari pembuatan aplikasi absensi peserta ini adalah untuk membuat suatu aplikasi pengelolaan data absensi harian peserta berbasis database. Tujuan yang akan diperoleh dari sistem informasi pendataan absensi peserta ini antara lain: Menghemat waktu dalam pengolahan data absensi, memperoleh keakuratan informasi yang lebih dibandingkan pengolahan data absensi secara manual, dan untuk data absensi yang dicantumkan adalah keterangan tidak masuk (Sakit, Ijin, Alpa, atau Terlambat), dan tanggal ketika peserta tersebut tidak masuk.

\section{Proses Normalisasi merupakan} proses pengelompokan data elemen menjadi tabel - tabel yang menunjukkan entity dan relasinya dari bentuk yang tidak normal, untuk dapat memperoleh bentuk tabel yang normal, maka dilakukan proses normalisasi. Tanpa normalisasi sistem database mejadi tidak akurat, lambat, tidak efisien serta tidak dapat memberikan data yang sesuai kebutuhan user.

Relasi antar tabel pada Gambar 1 menggambarkan sistem pengolahan data pegawai, presensi pegawai, data siswa dan siswa_presensi, yang menggambarkan hubungan berkas basis data melalui field field kuncinya dari sistem pengolahan yang di rancang.

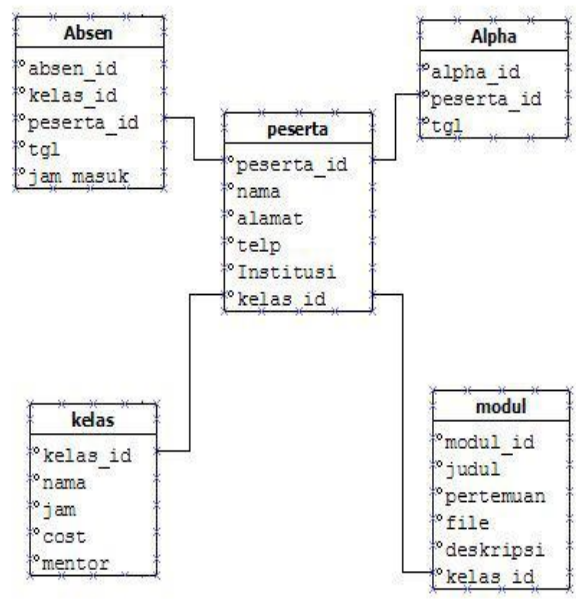

\section{Gambar 1. Relasi Tabel Peserta Bimbingan Belajar}

\section{IMPLEMENTASI}

Perancangan sistem berupaya menganalisa input data atau aliran data secara sistematis, memproses atau mentransformasikan data, menyimpan data, dan menghasilkan informasi. Perancangan sistem digunakan untuk menganalisa, merancang, dan mengimplementasikan peningkatan peningkatan fungsi yang bisa dicapai melalui penggunaan sistem informasi terkomputerisasi.

\section{Tampilan Program}

\section{Menu Utama}

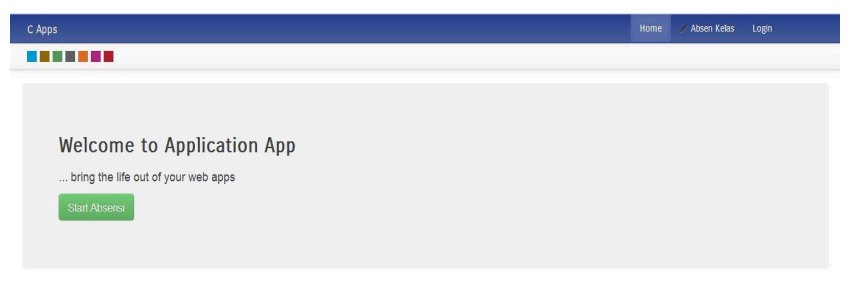

Gambar 2. Menu Utama

Pada gambar 2 menjelaskan halaman utama dari aplikasi yang menampilkan menu login seorang peserta untuk melakukan absensi.

\section{Tampilan Login}

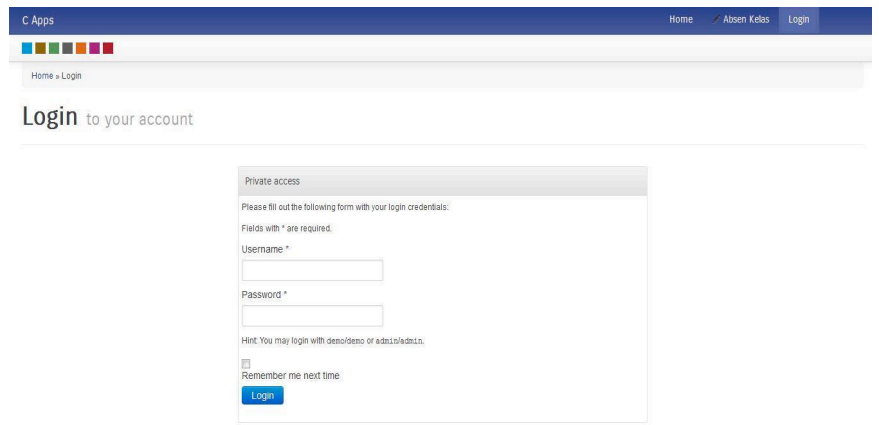




\section{Gambar 3. Tampilan Login}

Pada gambar 3 menjelaskan halaman login seorang peserta untuk melakukan absensi. Login Admin Username diisi nama user yang telah ada di MySQL, Password diisi dengan password user, tombol login digunakan untuk masuk ke menu admin

\section{Tampilan Absensi}

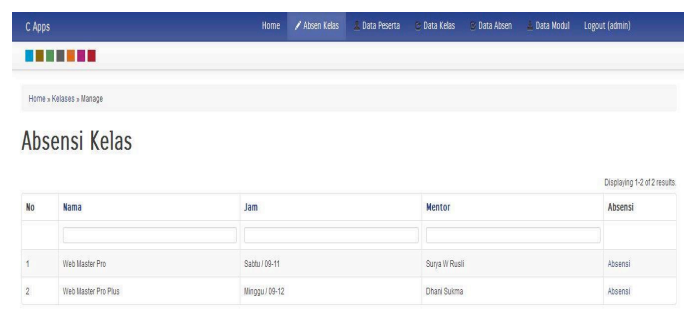

Gambar 4. Tampilan Absensi

Pada gambar 4 menjelaskan halaman absensi, saat dilakukan absen data masuk ke dalam database dan tampil pada aplikasi ini.

\section{KESIMPULAN}

Aplikasi Absensi peserta lembaga pembelajaran berbasis Web ini adalah media yang dapat digunakan untuk menyampaikan informasi khususnya pada pimpinan dan pembimbing. Aplikasi absensi peserta ini dirancang penulis dengan menggunakan Website berbasis Framework Yii, xampp sebagai web servernya, PHP bahasa scripting-nya dan MySQL sebagai database manajemen sistem (DBMS). Penggunaan dan pemanfaatan aplikasi absensi peserta berbasis web pada PT. Cyber Solution dapat memberikan kemudahan bagi pegawai PT. Cyber Solution untuk melakukan presensi, pimpinan dan pegawai dapat melihat langsung informasi absensi, memudahkan Pimpinan dan Staff kepegawaian mendapatkan rekapitulasi absensi secara online, dan data absensi lebih terstruktur dan tidak akan mudah tercecer lagi, karena sudah tersimpan secara terintegrasi melalui pengolahan database yang baik.

\section{DAFTAR PUSTAKA}

[1] S. Rintjap, Sherwin R.U.A, Sompie, and O. Lantang, "Aplikasi Absensi Siswa Menggunakan Sidik Jari di Sekolah Menengah Atas Negeri 9 Manado". Manado: Jurnal Teknik Elektro Dan Komputer UNSRAT Universitas Sam Batulangi Manado, 2014.

[2] A. T. Satria, "Rancang Bangun Sistem Absensi Karyawan Online Berbasis Web Menggunakan Framework PHP Codeigniter \& Mysql (Studi Kasus: PT. Starone Mitra Telekomunikasi)". Semarang: Jurnal TransIT Universitas Semarang Vol. 1 No. 1 pp. 53-65, Januari 2013.

[3] B. Permana, "Cepat Mahir Bahasa Pemrograman PHP". Diambil dari: http://ilmukomputer.org/wpcontent/uploads/2013/01/BudiCepat-Mahir-Bahasa-PemrogramanPHP.pdf, Diakses 9 Februari 2015.

[4] L. Anjaya, R. Lukito, and E. S. Djatikusuma, "Sistem Informasi Manajemen Kepegawaian Berbasis Web pada PT Bintang Baru Sejati Palembang”. Palembang: STMIK GI MDP, 2010.

[5] M. Rachman and C. A. W. Dini, "Aplikasi Absensi Pegawai Kecamatan Batuceper Tangerang Dalam Meningkatkan Akurasi Informasi". Tangerang: CCIT 
Journal Perguruan Tinggi Raharja Vol. 7 No. 2, Januari 2014.

[6] N. A. Muhammad, F. Samopa, and R. P. Wibowo, "Pembuatan Aplikasi Presensi Perkuliahan Berbasis Fingerprint (Studi Kasus : Jurusan Sistem Informasi Institut Teknologi Sepuluh Nopember Surabaya)". Surabaya: Jurnal Teknik POMITS Institut Teknologi Sepuluh November Vol. 2 No.3, 2013.

[7] R. Budi, "Belajar Otodidak Membuat Database Menggunakan MySQL." Bandung : Informatika, 2011.

[8] Yulianto, "Pengembangan SIS+ Pada Perguruan Tinggi Raharja Studi Kasus: Daftar Nilai dan Biodata Menggunakan Yii Framework". Tangerang: Laporan Skripsi, 2013. 